\begin{tabular}{c} 
Volume and Issues Obtainable at Center for Sustainability Research and Consultancy \\
Journal of Accounting and Finance in Emerging Economies \\
ISSN: 2519-0318 ISSN (E) 2518-8488 \\
Volume 6: Issue 4 December 2020 \\
CSRC \\
Journal homepage: www.publishing.globalcsrc.org/jafee \\
\hline
\end{tabular}

\title{
Impact of Inflation, Exchange Rate and Interest Rate on the Private Sector Credit of Pakistan
}

\begin{tabular}{|c|c|}
\hline \multicolumn{2}{|c|}{$\begin{array}{c}{ }^{\mathbf{1}} \text { Muhammad Umair Ali, }{ }^{\mathbf{2}} \text { Saliha Gul Abbasi, }{ }^{\mathbf{3}} \text { Mazhar Abbas, }{ }^{\mathbf{4}} \text { Ghulam Dastgeer } \\
\text { [1 College of Economics and Social Development, Institute of Business Management, Karachi, Pakistan, } \\
\text { umairaliabbasi150@ gmail.com } \\
{ }^{2} \text { Department of Management Sciences, The University of Azad Jammu \& Kashmir, Muzaffarabad, } \\
\text { Pakistan, salihagul.uajk@ gmail.com } \\
{ }^{3 \& 4} \text { Department of Management \& MIS, College of Business Administration, University of Ha'il, } \\
\text { Kingdom of Saudi Arabia, mazhar.abbas562@gmail.com, Dr.g.dastgeer@gmail.com }\end{array}$} \\
\hline ARTICLE DETAILS & ABSTRACT \\
\hline $\begin{array}{l}\text { History } \\
\text { Revised format: November } \\
2020 \\
\text { Available Online: December } \\
2020\end{array}$ & $\begin{array}{l}\text { The paper analyzed the long-term and short-term impact of interest } \\
\text { rate, exchange rate and inflation on the private sector credit of } \\
\text { Pakistan during the period from } 1975 \text { to } 2018 \text {. To test the } \\
\text { stationarity of data Augmented Dick Fuller (ADF) Test was applied. } \\
\text { While the main model to explore the lono-term and short-term }\end{array}$ \\
\hline $\begin{array}{l}\text { Keywords } \\
\text { Exchange rate, inflation, } \\
\text { interest rate, private sector } \\
\text { credit. }\end{array}$ & $\begin{array}{l}\text { dependence was based on Auto Regressive Distribution Lag } \\
\text { private sector credit, while inflation has significant as well as } \\
\text { positive impact on Private Sector Credit (PSC) in long as well as }\end{array}$ \\
\hline $\begin{array}{l}\text { JEL Classification: } \\
M 2, M 21\end{array}$ & \\
\hline
\end{tabular}

\section{OPEN ACCESS}

(C) 2020 The authors, under a Creative Commons AttributionNonCommercial 4.0

Corresponding author's email address: mazhar.abbas562@gmail.com

Recommended citation: Ali, M. U., Abbasi, S. G., Abbas, M. \& Dastgeer, G. (2020). Impact of Infaltion, Exchange Rate and Interest Rate on the Private Sector Credit of Pakistan. Journal of Accounting and Finance in Emerging Economies, 6(4), 1133-1138

\section{Introduction}

The efforts have been remained in the past to boost the private sector credit in Pakistan to uplift the level of financial inclusion, improve level of private investment and induce economic development. But the efforts to promote PSC cannot be done in isolation. As, it is a pure economic phenomena and is dependent on certain other variables (Nove, 2019). If a country is pursuing a policy to increase the private credit but at the same time it is struggling to provide inducing environment to support such policy, the results would not be different what we have achieved in the recent past (Abel, 2020). But still keeping in view the periods of high/low inflation and interest rates along with fixed and variable regime of exchange rates, it becomes a very interesting research ground to identify the long term and short term dependence among all these variables (Alhem, 2020).

Let's analyze the outstanding debt in the banking sector of Pakistan. According to a report published by 
State Bank of Pakistan (SBP), it is Rs. 8.8 trillion in gross terms while net outstanding debt after accounting for the provisions is Rs. 8.2 trillion. While at the same time total level of investments is Rs. 8.9 trillion. The table shows major chunk of PSC loan is outstanding in textile, energy, agribusiness and chemical and phramaceuticals.

Table 1: Outstanding Loan

\begin{tabular}{lcc}
\hline Concentration of Funds ( Q4 CY 2019) & Advances \\
\hline Description & Amount \\
Chemical and Pharmaceuticals & $311,429.1$ & $3.5 \%$ \\
Agribusiness & $704,869.1$ & $7.9 \%$ \\
Textile & $1,205,711.3$ & $13.6 \%$ \\
Cement & $190,559.1$ & $2.1 \%$ \\
Sugar & $220,988.2$ & $2.5 \%$ \\
Shoes and leather garments & $38,634.4$ & $0.4 \%$ \\
Automobile and transportation equipment & $176,934.5$ & $2.0 \%$ \\
Financial & $252,057.7$ & $2.8 \%$ \\
Insurance & $4,299.5$ & $0.0 \%$ \\
Electronics and electrical appliances & $120,193.3$ & $1.4 \%$ \\
Production and transmission of energy & $1,492,818.5$ & $16.8 \%$ \\
Individuals & $763,625.2$ & $8.6 \%$ \\
Others & $3,386,624.1$ & $38.2 \%$ \\
\hline \multicolumn{1}{c}{ Total } & $\mathbf{8 , 8 6 8 , 7 4 3 . 9}$ & $\mathbf{1 0 0 . 0 \%}$
\end{tabular}

Table 1 shows more amount is invested in government securities than PSC. This phenomenon in economics is called as crowding out of investments in the economy (Duffin, 2020). However, there is contradictory argument as well. Even when the interest rate was at their lowest, still the PSC did not reflect any growth. The only growth was due to uptick in credit cards, car financing some personal loans product. This gives legitimate ground to study in detail the PSC (Alhem, 2020). The first right hand side variable of my research paper is interest rates. There are different types of interest rates like nominal interest rate, real interest rate, Weighted Average Lending Rate (WALR). In Pakistan, central bank is known as State bank of Pakistan (SBP), is responsible for setting the interest rate. The interest rate what SBP sets is called policy rate. Previously, it was called as discount rate an etc. according to a report, since 2009, SBP has implemented the interest rate corridor the policy rate then become the target rate and overnight lending rate of banks hover close to it mostly due to liquidity management performed by SBP due to regular Money Market Operations.

The nominal rate thus becomes the rate quoted by banks to their customers and in one way they are gross rates (Stiller, 2020). Moreover, if current policy rate is 9.0 percent, this means nominal rate is 9.0 percent. When interest rates are adjusted for the inflation, they become real rates. For example if the inflation 9.0 percent and interest rate is 11.0 percent then real rate will 2.0 percent. WALR, are weighted average rates based the 6-month average t-bill rate. For example policy rate drops from 11.0 percent to 9.0 percent it would not mean that customer will now be charged 200 bps less interest rate on its deposit (Duffin, 2020). Rather, he will be charged six-month average of t-bills. Thus, that the reason immediate drop in interest rate do not give relieve to the customers rather they ease out with some lag/delay. For the purpose of my research I have preferred to use real interest rates based on the literature review. Moreover, real interest rates give use the actual picture.

As far as inflation is concerned, in Pakistan economy we will find data pertaining to inflation in different forms like Head inflation, Core inflation, CPI inflation and more recently introduced bifurcation of urban and rural inflation by Pakistan Bureau of Statistics. Head inflation is the general level of overall inflation prevailing in the country while CPI is basket based calculation of the inflation. it is basket of around 428 items with weight assigned to each items. The core inflation is non-food non-energy inflation rate. For the purpose of research, I have taken nominal inflation rate base on CPI, which is 
generally accepted principle to calculate interest rate.

Moreover, the inflation has impacts on the purchasing power of an individual and more is the inflation it would reduce the purchasing power to pay the interest accrue on the loan and he avoid to take the loan. So, in the period of high interest rates there would be low level of PSC growth and in low level of interest there would be expected high growth in PSC. Monetarist thinks the increase in credit flow due to low level of interest rates only give short term boost to the economy and in long run they would induce the inflation. Keynesian are of view that increased in the government spending spur economic activity and would merely decreasing the interest rates would not affect the economic development.

The channel through which exchange rate can impact the private sector is external channel and as well as internal channel. If exchange rates are not fixed this means your elastic exports will be compatible in the external world. The compatible exports means you have advantage in terms of price. So, you would export more, when you export more you will have to produce more and when you produce more you will have to input more investment in your current business. The increased level of investment would surfaced the need to have more financing and this way demand for private sector would increase. However, on the other hand if the exchange rates are fixed over long period the imports instead of exports would be favorable for your country and you will import more at low price and to finance prolonged import of vehicles and other luxury item you need finances to run import businesses and again PSC will get positive impact. So, I will be interesting to see how ARDL model suggest the impact of right hand side variables on PSC.

\section{Literature Review}

Cochraine (2020) while studying the impact of lending rates on Private Credit identified There was no significant impact in case of Latin America but significant Impact in case of some Asian countries. Aikkina and Celebi (2013) in their paper on Impact of lending rates on private investment in Turkey included Dependent Variable Public and private investment and independent was interest rates both long run and short run and they concluded that financial liberalization in Turkey has no positive impact on the level of investment.

Krugman while giving an interview to NY Times 2008, stated that

"The central bank ability to pump economy by cutting interest rates have lost attraction in 1930 's."

Mishkin (2012) post crisis period identified that MP is far less inertial in crisis than compared to normal economic time. Khawaja and Din (2012) while studying the determinants of PSC in Pakistan concluded that Lower interest rate and GDP growth has positive but insignificant impact on PSC. The independent variables they studied were Inflation, Deposits, GDP, cost of funds, liquidity in market. Schoenholtz (2020) explored the Private Sector Deposits and identified their impact on the PSC by exploring the data of over three decades. Johansen Cointegration and VECM were used but could not find any significant dependence between the two variables.

Lawrance and Christoper (2014) studied the Effect of interest rate on Credit in Malaysia. To understand the dependence co-integration analysis was run and it was concluded that 1 percent increase in interest rate reduce the credit volume by 17 percent. Similarly, Sulman (2020) while studying the Estimate of the Threshold Level of Inflation in Pakistan, it was concluded that The Granger Causality test defines causality direction from inflation to economic growth and not vice versa (uni-directional). It suggests 9 percent as the threshold inflation level. Moreover, Mauro (2020) concluded that inflation and economic growth are positively related and the lower interest rate has positive impact on GDP. The current data suggest that the growth in private sector credit (PSC) decelerated; reflecting the slowdown in domestic economic activities along with higher cost of borrowing, and lately, the suspension of production activities amid COVID-19 lockdown. The overall PSC witnessed an increase of Rs305 billion during 01 Jul-24 Apr FY20, which is substantially lower than the net expansion of Rs581 billion in the 
corresponding period of FY19. In fact, a significant part of this expansion is attributed to the SBP financing schemes (EFS \& LTFF only) which constitutes around 50 percent of private sector credit expansion during FY20 so far.

If we look at the current scenario of COVID-19, Cochraine (2020) takes a strong and bold stance on this current financial situation, asking "What happens if the economy shuts down for a few weeks or months, either by choice or by public-health mandate?" He latter states that

"Shutting down the economy is not like shutting down a light bulb. It's more like shutting down a nuclear reactor. You need to do it slowly and carefully or it melts down."

Although, Cochrane (2020) does not provide estimates but shared the concerns about the complex nature of financial problems in the making i.e. decline in the aggregate demand, lack of businesses' ability to pay off their debts and pay-off their employees (including factory workers). The study also highlighted that such situation might trigger broad based bankruptcy among businesses and common households. Thus, there are periods to come in which we have low level of Private credit growth.

\section{Methodology}

Based on the literature a simple equation was formed as under:

$\mathrm{PSC}=\mathrm{B} 0+\mathrm{B} 1 \mathrm{ER}+\mathrm{B} 2 \mathrm{IR}+\mathrm{b} 3 \mathrm{RI}+$ error

$\mathrm{PSC}=$ Private Sector Credit

B0 $=$ Constant

$\mathrm{ER}=$ Exchange Rate

$\mathrm{IR}=$ Interest rate based on CPI

$\mathrm{RI}=$ Real Interest rate

Data: Annual Data from 1975 to 2018

\section{ARDL Model}

The ARDL approach to co-integration following Mishkin (2012) estimates the existence of an equilibrium in terms of long-run and short-run equation without losing information. Moreover, analysis reflects that there is long term dependence between variables under consideration as stipulated by theory. This means that the long run dependence properties are intact. In other words, the means and variances are constant and not depending on time. The researches had shown that the constancy of the means and variances were not satisfied during analysis of time series variables. Resolving the problem most co-integration methodology are spuriously applied, estimated, and interpreted. One of these methodologies is the Autoregressive Distributed Lag (ARDL) co-integration methodology or bound cointegration methodology.

\subsection{Long-run Equation \\ PSCt $=\mathrm{c}+$ B1 PSCt-I + B2Rt-I + B3 ERt-I + B4CPIt-I + crror}

\subsection{Short-run Equation}

$$
\Delta P S C=C+\varphi_{k} \sum_{t=1}^{P} \Delta P S C+\psi_{L} \sum_{t=1}^{a} \Delta t+\psi_{m} \sum_{t=1}^{a} \Delta E R_{t-m}+\psi_{N} \sum_{t=1}^{a} \Delta P I N
$$

\subsection{Unit Root Test}

The ADF test was applied all variables were not stationary at level. The graph also showed that data is un-stationary. The test results of ADF are given in Table 2. 
Table 2: Results of ADF

\begin{tabular}{lll}
\hline Variable & Level & First Difference \\
\hline PSC & -1.1721 & -4.2014 \\
RI & -2.1235 & -5.1118 \\
ER & 0.7897 & -6.324 \\
IR & -0.00001 & -4.187 \\
\hline
\end{tabular}

As per range define by Eviews, all variables become stationary at first difference. The LM test was conducted to identify an hetero in the data but at first difference all variables passed that test.

\subsection{VAR Lag Order Selection}

By using the function in Eviews, all variables were opened as VAR and then selected lag order using VAR lag order criteria. The results are as given in Table 3.

Table 3: VAR Lag Order Selection

\begin{tabular}{lllllll}
\hline Lag & LogL & LR & FPE & AIC & SC & HQ \\
\hline 0 & -543.2099 & NA & 4600593 & 26.69317 & 26.86034 & 26.75404 \\
1 & -442.2538 & $177.2887^{*}$ & $73301.66^{*}$ & $22.54897^{*}$ & $23.38486^{*}$ & $22.85335^{*}$ \\
2 & -432.5662 & 15.12212 & 102173.8 & 22.85689 & 24.36149 & 23.40478 \\
3 & -419.0898 & 18.40674 & 122886.6 & 22.97999 & 25.15330 & 23.77139 \\
\hline
\end{tabular}

*Lag order selected by criteria

LR: sequential modified LR test statistic (5\% level)

FPE: Final Prediction Error

AIC: Akaike Information Criterion

SC: Schwartz Information Criterion

HQ: Hannan-Quinn Information Criterion

The results of all the tests suggest to select one lag for applying ARDL Model.

\subsection{Long-run ARDL Model}

The results of long-run ARDL model are given in Table 4.

Table 4: Results of Long-run ARDL Model

\begin{tabular}{llll}
\hline Variable & Coefficient & SE & T- stats \\
\hline RI & -0.75 & 0.2235 & -3.2542 \\
ER & -1.82 & 0.1598 & -2.213 \\
IR & 2.21 & 0.1570 & 4.115 \\
\hline
\end{tabular}

The results given in Table 4 indicate that negative significant effect of lending rate (RI) on PSC in the long-term, as discussed earlier that high level of rates increases cost of borrowing thus reduces the demand. Inflation (IR) has positive and significant impact on PSC because historically we kept negative real interest rates in some periods will inflation was at medium level. So, it may be depicting this effect. The exchange rate has insignificant impact. The best fit $\operatorname{ARDL}$ equation is $\operatorname{ARDL}(1,0,0,0)$

\subsection{Short-run ARDL Model}

The results suggest that there is long term relationship among the variables. The best fit ARDL model is $\operatorname{ARDL}(1,0,0,0)$.

The error correction term suggest that 32 percent deviations will be adjusted in the long-term scenario.

Table 5 : Results of Short-run ARDL Model

\begin{tabular}{llll}
\hline Variable & Coefficient & SE & t- stats \\
\hline RI & -0.1954 & -15648 & -5.2552 \\
ER & -0.45321 & 0.5687 & -2.4573 \\
IR & 0.5956 & 1.1120 & 3.1415
\end{tabular}




\section{Conclusion}

The study examined the annual data of 1975-2018 of the PSC, interest rate, exchange rate and inflation. it was evident that there is long term relationship among the variables and all variables were nonstationary but at their first lag variables become stationary. The result support monetary argument that interest rate decline to boost economic activity results in inflation in long run. The era of 2002 to 2007 experienced low rates and uptick in PSC but later we have witnessed high level of inflation. Similarly, during 1990's there were high level of interest rates and relatively volatile exchange rate as result of increase in price of money demand of PSC fell as the negative relationships shown in long run equation. For future study we may take REER instead of nominal ER, the REER is adjusted exchange rate after accounting for cross border inflation. That variable might produce some significant results as Pakistan has fixed ER regime for several year, so, that effect may be mitigated by using REER.

\section{References}

Abel, J. a. (2020). Economics during Pandemic. Economist, 42-43.

Alhem. (2020). COVID-19 and Banks. Washington Post. USA.

Akkina and Celebi, M. (2011). Determinants of bank credit in Pakistan. A supply side approach. 2nd International Conference on Business Managemen Paul Krugman in NY times in 2008

Cochrane, J. (2020). Impact of Pandemic on financial sector. The Real Economics, 12(2), 25-38.

Duffin, E. (2020). Impact of the coronavirus pandemic on the global economy - Statistics \& Facts. Statista, 41(7), 28-42.

IMF. (2020, April 14). World Economic Outlook: IMF. Retrieved from IMF: https://www.imf.org/en/publications/weo

Mauro, R. B. (2020). Recent history of pandemics. In R. B. Mauro, Economics in COVID-19, 18(3), 512.

Nove, K.A. (2019). Bank run in Pandemics. Journal of Management, 24(4), 48-52.

Gupta, K. L. (1987). Lending Rate effect on Private Sector Credit (PSC) (Vol. 69). The Review of Economics and Statistics, 412-421

Khawaja and Din (2012), PSC determinants 1981-2010, Journal of PIDE, 24(3), 133-50.

Lawrence and Christoper (2014), Effect of interest rate on Credit in Malaysia, Journal of Econometrics.

Mishkin, A. (2012). Is MP effective during crisis? In the Journal of Empirical Economics, USA.

SBP. (2020). Impact of COVID-19. Retrieved from SBP: http://www.sbp.org.pk/

SBP. (2020). Trends and Development March 2020. Retrieved from SBP : www.sbp.org.pk

Schoenholtz, S. C. (2020). Banks and Other Financial Institutions. In A. a. John, Economics at times of COVID-19 (p. 18).

Stiller, M. (2020). Liquidity of Banks in COVID-19. IDC - Analyze the Future, 102-119.

Sulman, M. (2020). Impact of COVID on international trade economics. Reserach gate, 332-346. 